\title{
THE MECHANISM OF HEMOLYSIS IN PAROXYSMAL COLD HEMOGLOBINURIA. II. OBSERVATIONS ON THE BE- HAVIOR AND NATURE OF THE ANTIBODY ${ }^{1}$
}

\author{
By WILLIAM S. JORDAN, JR., LOUIS PILLEMER, AND JOHN H. DINGLE
}

(From the Departments of Preventive Medicine and of Medicine, and the Institute of Pathology, School of Medicine, Western Reserve University, and the University Hospitals, Cleveland, Ohio)

(Submitted for publication July 24, 1950; accepted, October 3, 1950)

The abnormal factor responsible for hemolysis in paroxysmal cold hemoglobinuria $(\mathrm{PCH})$ is present in the patient's serum (1). As a result of infection with the spirochete of syphilis $(2,3)$, the patient produces a factor that, under proper conditions, hemolyzes his own erythrocytes. Hemoglobinuria is thus a dramatic manifestation of the ability of an infectious agent to induce the body to destroy one of its tissues. Such "auto-immunization" is not dependent on any specific blood group antigen $(2,3)$, and the serum antibody is active not only against the patient's erythrocytes but also against erythrocytes from other individuals.

The hemolysin is activated in an antigen-antibody-complement system (1-4). When erythrocytes and $\mathrm{PCH}$ serum are chilled, antibody fixation occurs in the presence of complement. When the sensitized erythrocytes are warmed in the presence of complement, hemolysis occurs. Recent studies have indicated that this system is not only unique in requiring complement for antibody fixation as well as for subsequent hemolysis, but that it is also unusual in requiring only two of the four components of complement for hemolysis. Hemolysis occurs in the absence of two components, $\mathrm{C}^{\prime} 1$ and $C^{\prime} 3$. Hemolysis does not occur in the absence of components $C^{\prime} 2$ and $C^{\prime} 4$. $C^{\prime} 4$ is apparently required in the cold phase, $\mathrm{C}^{\prime} 2$ in the warm phase (4).

It was also found that the hemolysins from two patients were stable at $62^{\circ} \mathrm{C}$, apparent heat-lability being attributable to failure to use sufficient complement for reactivation (4). The use of antiglobulin serum (4-6) provided a new technique for identifying and measuring this abnormal anti-

\footnotetext{
1 This investigation was supported in part by grants from the Brush Foundation, the Cleveland Foundation, the S. P. Fenn Trust and Mr. Philip R. Mather.
}

body. The present report concerns further investigations on the behavior of the antibody, in the course of which it seemed desirable to attempt the isolation and characterization of the hemolysin.

\section{MATERIALS AND METHODS}

The case histories of the two patients with paroxysmal cold hemoglobinuria have been summarized elsewhere (4). One of the patients, case 1, was observed before antiglobulin serum was available, and her erythrocytes were not tested in the direct Coombs test. Specimens of her serum, stored for approximately ten months at $-20^{\circ} \mathrm{C}$, were available. Thus, erythrocytes from case 2 and sera from both casès were tested.

The methods used for the following procedures were those previously described (4): 1) Hemolysin titration, 2) Direct Coombs test, 3) Indirect Coombs tests, (a) and (b), and 4) Complement titration. Plasma fractions were assayed for antibody by substituting each of the fractions for $\mathrm{PCH}$ serum in these tests.

\section{Fractionation of Plasma}

In a series of orientation experiments, $400 \mathrm{ml}$. of plasma from case 2 were dialyzed against repeated changes of acetate buffer of $\mathrm{pH} 5.3$, ionic strength 0.02 , at $0^{\circ} \mathrm{C}$. After dialysis for 72 hours the precipitate was removed by centrifugation at $0^{\circ} \mathrm{C}$, washed two times with $\mathrm{pH}$ 5.3 buffer and redissolved to a volume of $80 \mathrm{ml}$. in $\mathrm{M} / 15$ phosphate buffer of $\mathrm{pH} 7.4$ (Fraction PI).

Aliquots of the material soluble at $\mathrm{pH} 5.3$ (SI) were dialyzed against buffers between $\mathrm{pH} 5.0$ and 7.0, ionic strength 0.02 , for 72 hours at $0^{\circ} \mathrm{C}$, and the precipitates removed by centrifugation. The remainder of SI was fractionated with certain modifications according to the methods developed by Cohn and his associates (7-9) into Fractions II + III, IV, and V. Methanol was employed instead of ethanol, however, as the organic precipitating agent. Four hundred and fifty $\mathrm{ml}$. of SI were adjusted to ionic strength 0.1 with sodium chloride and to $\mathrm{pH} 6.9$ with sodium hydroxide. The material was chilled to the freezing point and methanol, previously chilled to $-25^{\circ} \mathrm{C}$, was added slowly with stirring. The temperature was maintained near the freezing point, and at $-5^{\circ} \mathrm{C}$ at the end of the alcohol addition. The mixture was allowed to stand overnight in $\mathrm{a}-5^{\circ} \mathrm{C}$ bath and then 
centrifuged at $-5^{\circ} \mathrm{C}$ for one hour at 4000 r.p.m. The precipitate (II + III) was dissolved up to $80 \mathrm{ml}$. in 0.15 sodium acetate. Sufficient thrombin was added, and the fibrin was removed by centrifugation. The material soluble at $\mathrm{pH} 6.9$, ionic strength 0.27 in 25 per cent methanol (SII + III) was adjusted to $\mathrm{pH} 5.7$ with acetic acid, and sufficient alcohol was added to bring the final concentration to 40 per cent. The precipitate (IV) was removed by centrifugation at $-5^{\circ} \mathrm{C}$ for one hour at 4000 r.p.m. and dissolved to a final volume of $80 \mathrm{ml}$. in 0.15 sodium acetate. The material soluble at $\mathrm{pH} 5.7$ in 40 per cent methanol (SIV) was adjusted to $\mathrm{pH} 4.7$ with acetic acid. Sufficient alcohol was again added to maintain the concentration at 40 per cent. The material insoluble (V) under these conditions was removed by centrifugation, and dissolved up to $160 \mathrm{ml}$. in sodium acetate.

Sixty-seven $\mathrm{ml}$. of II + III were dialyzed against repeated changes of water at $0^{\circ}$ for 96 hours. The precipitate (II +IIIE) was removed by centrifugation at $0^{\circ} \mathrm{C}$ for one hour at 4000 r.p.m. and dissolved up to 67 ml. in phosphate buffer of $\mathrm{pH}$ 7.4. The material soluble in water was labeled II + IIIS. Because PCH antibody was distributed between II + IIIS and II + IIIE, these fractions were combined (II + III) and were fractionated according to the methods of Deutsch and his associates (10) with certain modifications. One hundred $\mathrm{ml}$. of II + III were adjusted to $\mathrm{pH} 5.1$ with acetic acid and sufficient water added to bring the final volume to $700 \mathrm{ml}$. at $0^{\circ} \mathrm{C}$. Methanol was added to bring the final alcohol concentration to 17 per cent. The final conditions were $\mathrm{pH} 5.1$, ionic strength 0.01 , methanol concentration 17 per cent at $-5^{\circ} \mathrm{C}$. The material insoluble (III - I) under these conditions was removed by centrifugation at $-5^{\circ} \mathrm{C}$, and dissolved up to $25 \mathrm{ml}$. in phosphate buffer at $\mathrm{pH}$ 7.4. The material soluble under the above mentioned conditions was precipitated at $\mathrm{pH}$ 7.0, 25 per cent methanol, ionic strength 0.01 at $-5^{\circ} \mathrm{C}$. This precipitate was removed by centrifugation and labeled II. Fractions III - I and II were dissolved in water, dried from the frozen state, and reconstituted to $25 \mathrm{ml}$. in phosphate buffer of $\mathrm{pH} 7.4$. Five ml. of Fraction II were dialyzed for 72 hours against 4 liters of distilled water at $0^{\circ} \mathrm{C}$. The precipitate was removed by centrifugation and labeled IIE. The supernatant was labeled IIS.

\section{RESULTS}

The antibody in the sera of patients with paroxysmal cold hemoglobinuria can be detected and measured not only because it acts as a hemolysin but also because its presence on erythrocytes renders the cells agglutinable in antiglobulin serum $(4,6)$. The patient's red cells and control cells adsorb antibody in vitro when chilled with complement in $\mathrm{PCH}$ serum, and such sensitized cells are then hemolyzed when warmed with complement (Donath-Landsteiner reaction) or agglutinated when incubated with antiglobulin serum (indirect Coombs test).

It was noted that erythrocytes from case 2 were directly agglutinable in antiglobulin serum. Despite this indication of in vivo "sensitization," there was no evidence of in vivo hemolysis, nor were the direct Coombs-positive cells, presumably already coated with antibody, hemolyzed in vitro when warmed with complement. Variations in the agglutinability of the patient's cells occurred following induced attacks of hemolysis although no change in serum antibody was detected. These findings raised a number of questions : $a$ ) what is the nature of the abnormal factor ("cell antibody") adsorbed in vivo? b) is the "cell antibody" detected in the direct Coombs test the same as the serum antibody detected in the indirect Coombs test? $c$ ) is the serum antibody detected in the indirect Coombs test the same as the hemolysin? d) what is the nature of the serum antibody? The findings are presented by detailing the observations that prompted these questions and by describing the studies carried out in an attempt to answer them.

\section{Variation in agglutinability of $P C H$ erythrocytes in antiglobulin serum (direct Coombs test) following attacks of hemoglobinuria}

When erythrocytes initially obtained from case 2 were washed and incubated in antiglobulin serum (direct Coombs test), the cells were strongly agglutinated. The patient's erythrocytes, drawn five days after his last attack of hemoglobinuria, and promptly separated from defibrinated blood without chilling, were agglutinated by a 1-128 dilution, the effective titer (4), of the antiglobulin serum. The Donath-Landsteiner reaction was positive, the hemolysin titer was 4 , and the serum contained one unit of complement activity in $\mathbf{0 . 1 5}$ ml. of a 1-10 dilution. The Coombs test indicated that there was an abnormal serum protein, presumably the $\mathrm{PCH}$ hemolysin, on the surface of the erythrocytes. Although the cells were "sensitized" and complement was present, there were no signs of in vivo hemolysis. Hemolysis occurred, however, when the patient was chilled.

The detailed hematological changes will be described elsewhere (11). It need only be noted here that the maximum levels of serum hemoglobin were detected in the specimens obtained im- 
mediately after the ten-minute periods of chilling. The output of urine hemoglobin was maximum in the first hour after chilling. Although the hemolysis of erythrocytes occurred promptly, it is apparent (Table I) that the change in the direct Coombs titer was delayed. During and two and four hours after each of three induced attacks, there was no significant change in the agglutinability of the patient's erythrocytes in antiglobulin serum. In each instance, however, the cells were no longer agglutinable six hours after the attack. After the first two attacks, the direct Coombs test again became positive after intervals of two and 14 days, respectively. The patient was discharged after the third induced attack and has continued to suffer spontaneous attacks when exposed to cold. The direct Coombs titer has never returned to its original level, but the patient's erythrocytes have continued to show varying agglutinability in antiglobulin serum (Table I).

There was no significant change in the antibody content of sera obtained before, during and after attacks, as measured by both hemolysin titration and the indirect Coombs test (b). The same was true of similar sera from case 1 . At a time when the direct Coombs test was negative, the patient's serum showed complement activity (one unit in $0.2 \mathrm{ml}$. of 1-15 dilution) against sensitized sheep cells. The role of the individual components of complement (4) was not appreciated at that time, and the activity of components was not measured.

The reversion of the cells from Coombs-positive to -negative was not due to the fact that they had become refractory to the adsorption of antibody. Such cells, tested in serum drawn at the same time, behaved like normal cells in the indirect Coombs tests and the Donath-Landsteiner reaction. Nor did the patient's Coombs-negative cells adsorb any component from normal serum which made them Coombs-positive.

Comment: In certain cases of acquired hemolytic anemia the severity of hemolysis parallels the degree of erythrocyte sensitization (12). One would logically expect the $\mathrm{PCH}$ sensitized cells to be destroyed during the period of active hemolysis and to disappear from the circulation. In the instance described, on the contrary, sensitized cells remained in the circulation long after hemolysis had ceased, and the subsequent disappearance of evidence of sensitization could not be ascribed to red cell destruction. No concomitant change in serum antibody level was detected. Exhaustion of the complement component necessary for antibody fixation is a theoretical explanation $(3,4)$ yet to be tested, but it seems an unlikely possibility since there was no qualitative change in the complement activity of the patient's serum. There is, therefore, no satisfactory explanation for the disappearance of the direct agglutinability of the patient's erythrocytes.

A clue as to why the cells were directly agglutinable was obtained when it was noted that the direct Coombs test again became positive, following the first induced attack, after the patient's ward had been chilled while window-washers were at work. No such incident, however, was noted after the second induced attack. The patient continued to have spontaneous attacks following discharge, and as long as cold weather persisted, his cells were often agglutinable in the direct Coombs test. With the advent of warm weather attacks ceased and his erothrocytes were no longer Coombspositive. These events suggest that the in vivo "sensitization" detected in the direct Coombs test was induced by chilling, but that, as mentioned below, additional chilling in $\mathrm{PCH}$ serum was necessary to cause hemolysis.

\section{In vitro behavior of erythrocytes "sensitized" (direct Coombs-positive) in vivo}

Hemolysis: Because erythrocytes obtained from case 2 were directly agglutinable by antiglobulin serum without chilling in vitro in $\mathrm{PCH}$ serum, it was thought that these cells might be hemolyzed in the warm phase of the Donath-Landsteiner reaction. The patient's Coombs-positive, "sensitized" cells were treated as follows in an effort to produce in vitro hemolysis :

a) $0.25 \mathrm{ml}$. of $5 \%$ cell suspension $+0.25 \mathrm{ml}$. of $1-2$ guinea pig complement; incubated $37^{\circ} \mathrm{C}$ for 30 minutes.

b) $0.25 \mathrm{ml}$. of $5 \%$ cell suspension $+0.25 \mathrm{ml}$. of $1-2$ guinea pig complement; chilled in ice bath for 30 minutes and incubated $37^{\circ} \mathrm{C}$ for 30 minutes.

c) and $d$ ) Above steps repeated with addition of 0.25 ml. of fresh normal human serum.

No hemolysis occurred. The patient's cells and control cells were then chilled and warmed with guinea pig complement in the patient's serum (Donath-Landsteiner reaction). The cells were 
hemolyzed, and the degree of hemolysis of patient and control cells was the same.

The patient's erythrocytes, apparently already coated with antibody, and normal cells were then chilled in separate samples of the patient's serum, washed and tested with antiglobulin serum. Both patient and control cells were agglutinated by a 1-128 dilution of the antiglobulin serum. It thus was not possible by this technique to indicate that the direct Coombs-positive cells had adsorbed additional antibody.

The behavior of the patient's cells was further compared with normal erythrocytes. Cells from two other group B individuals and from three group 0 individuals showed the same capacity as the patient's cells for adsorbing antibody and were equally sensitive to hemolysis. Furthermore, in the Donath-Landsteiner and indirect Coombs tests, there was no demonstrable difference between the patient's cells whether they were or were not initially agglutinable in the direct Coombs test.

Since erythrocyte age is an important factor in normal cell destruction, the ability of the $\mathrm{PCH}$ hemolysin to lyze all erythrocytes was tested. When a small volume of cells was used in the Donath-Landsteiner reaction $(2,4)$ nearly all of the cells were lyzed. When a larger volume of cells was used (4), hemolysis was not complete. The cells remaining after the first incubation were washed and again chilled and warmed in $\mathrm{PCH}$

TABLE I

Variations in agglutinability of PCH erythrocytes in antiglobulin serum following attacks of hemoglobinuria

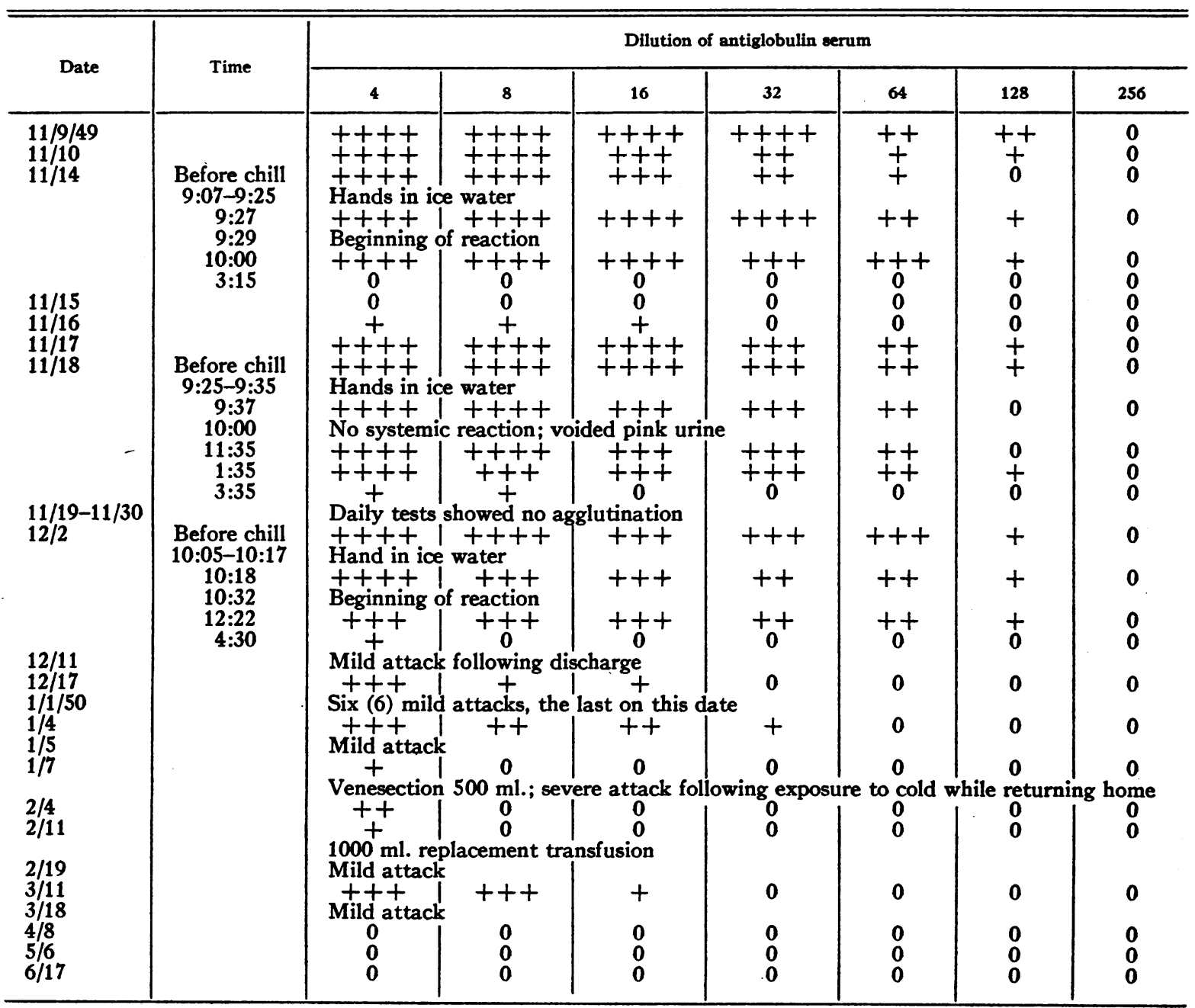

+ to $++++=$ Increasing degrees of agglutination; ++++ indicates disc formation. 
serum and complement. All erythrocytes were hemolyzed following the third incubation.

Elution: Because serum antibody can be eluted from erythrocytes (see below), an attempt was made to elute "cell antibody" from the patient's direct Coombs-positive cells. Erythrocytes from case 2 showing agglutinability in a 1-128 dilution of antiglobulin serum were suspended in saline, heated at $56^{\circ} \mathrm{C}$ for five minutes, and then washed. The cells were no longer agglutinated by a $1-4$ dilution of antiglobulin serum suggesting that the antibody had been eluted, but no antibody could be demonstrated in the supernatant fluid.

Comment: The nature of the cell antibody could not be determined. While the direct Coombs test indicated only whether cell antibody was present or absent, these changes in agglutinability of the patient's cells could be correlated with clinical events. Chilling seemed to be responsible for the in vivo "sensitization" detected by the direct Coombs test. More severe chilling produced hemolysis, and this was followed by a delayed, but consistent, disappearance of in vivo "sensitization." Certain of the results obtained when the direct Coombspositive cells were tested in vitro could, in turn, be related to the observations in vivo.

The patient's washed cells were agglutinated in high dilutions of antiglobulin serum; after the erythrocytes were chilled in $\mathrm{PCH}$ serum, no additional antibody on the surface of the cells could be detected with antiglobulin serum (indirect Coombs test [a]). This test does not distinguish between cells chilled in sera with an eight to 16-fold difference in antibody titer (4) and it may be that the patient's "sensitized" cells did adsorb more antibody. At least a change of antigen-antibody union had occurred, for the cells now hemolyzed when warmed with complement. It is evident that the antibody fixed in vivo did not block the in vitro action of antibody from the same serum. Nor did it block in vivo action of the antibody, since the patient had hemolytic crises after chilling.

An explanation for the behavior of the patient's erythrocytes can only be surmised. Although already "sensitized," the cells had to be chilled in $\mathrm{PCH}$ serum, both in vitro and in vivo, before hemolysis would occur. Since less complement is needed in the cold phase of the Donath-Landsteiner reaction for antibody fixation than is needed for subsequent hemolysis (4), it may be that chilling was necessary to fix more complement. When the "sensitized" cells were both chilled and warmed in complement, however, hemolysis did not occur. Other possible explanations are that more antibody had to be fixed, that reorientation of the erythrocyte-complement-antibody complex was necessary to promote hemolysis, or that a factor other than $\mathrm{PCH}$ antibody had been adsorbed by the cells. Because the substance responsible for direct agglutination of the patient's cells in antiglobulin serum could not be demonstrated in eluates, identification of this substance as the $\mathrm{PCH}$ serum antibody was not possible. Since, as indicated later, the serum factor responsible for agglutination in the indirect Coombs tests is the $\mathrm{PCH}$ hemolysin, the simplest working hypothesis is to assume that the substance reacting in the direct Coombs test is also $\mathrm{PCH}$ antibody.

\section{Elution of antibody; effect of heat on agglutin- ability of erythrocytes sensitized in vitro}

Blood group agglutinins (13) and $\mathrm{Rh}$ blocking antibodies (14) have been removed from erythrocytes by heating the cells at $56^{\circ} \mathrm{C}$. Antibodies were demonstrated in the supernatant fluids by using the eluates to sensitize other erythrocytes. Several investigators $(12,15,16)$ have similarly been able to elute the substance reacting with antiglobulin serum from the erythrocytes of patients with acquired hemolytic anemia. Heating the direct Coombs-positive, in vivo "sensitized" erythrocytes from case 2 destroyed their agglutinability in antiglobulin serum, but antibody could not be demonstrated in the eluate.

An attempt was then made to elute antibody from cells sensitized in vitro. Group 0 cells were chilled with complement in serum from case 2 and were shown to agglutinate in a 1-128 dilution of antiglobulin serum (indirect Coombs test [a]). After heating at $56^{\circ} \mathrm{C}$ for five minutes, these cells were weakly agglutinated by a 1-8 dilution of antiglobulin serum. Repeated attempts to demonstrate antibody in eluates from such normal cells sensitized in the serum from case 2 were inconclusive. Using serum from case 1 with a higher titer (4), however, antibody was adsorbed, eluted and transferred to other cells.

The basic technique mentioned above (12-16) was used. One ml. of packed group 0 cells was added to a mixture of $2.5 \mathrm{ml}$. of serum from case 1 
TABLE II

The adsorption and elution of PCH antibody

Antibody in serum and eluate

\begin{tabular}{|c|c|c|c|c|c|c|c|c|c|}
\hline & \multicolumn{8}{|c|}{ Dilution of serum or eluate } \\
\hline & & Undiluted & 2 & 4 & 8 & 16 & 32 & 64 & 128 \\
\hline $\begin{array}{l}\text { Serum } \\
\text { Before adsorption }\end{array}$ & $\begin{array}{l}\mathrm{H}^{*} \\
\mathrm{~A} \dagger\end{array}$ & & & $\begin{array}{c}+++ \\
++++\end{array}$ & $\begin{array}{c}+++ \\
++++\end{array}$ & $\stackrel{++}{++}$ & $\stackrel{+}{++}$ & $\begin{array}{l}0 \\
+\end{array}$ & $\begin{array}{l}\mathbf{0} \\
\mathbf{0}\end{array}$ \\
\hline After adsorption & $\begin{array}{l}\mathrm{H}^{*} \\
\mathrm{~A} \dagger\end{array}$ & $\begin{array}{l}0 \\
0\end{array}$ & $\begin{array}{l}0 \\
0\end{array}$ & $\begin{array}{l}\mathbf{0} \\
\mathbf{0}\end{array}$ & $\begin{array}{l}\mathbf{0} \\
\mathbf{0}\end{array}$ & $\begin{array}{l}\mathbf{0} \\
\mathbf{0}\end{array}$ & $\begin{array}{l}\mathbf{0} \\
\mathbf{0}\end{array}$ & $\begin{array}{l}\mathbf{0} \\
\mathbf{0}\end{array}$ & $\begin{array}{l}\mathbf{0} \\
0\end{array}$ \\
\hline Eluate & $\begin{array}{l}\mathrm{H}^{*} \\
\mathrm{~A} \dagger\end{array}$ & $\begin{array}{c}+++ \\
++++\end{array}$ & $\begin{array}{l}+++ \\
+++\end{array}$ & $\begin{array}{l}++ \\
+++\end{array}$ & $\stackrel{+}{++}$ & $\begin{array}{l}0 \\
+\end{array}$ & $\begin{array}{l}\mathbf{0} \\
\mathbf{0}\end{array}$ & $\begin{array}{l}0 \\
0\end{array}$ & $\begin{array}{l}\mathbf{0} \\
0\end{array}$ \\
\hline
\end{tabular}

Antibody on erythrocytes $\ddagger$

\begin{tabular}{|c|c|c|c|c|c|c|c|}
\hline \multirow{2}{*}{ Erythrocytes } & \multicolumn{7}{|c|}{ Dilution of antiglobulin serum } \\
\hline & 4 & 8 & 16 & 32 & 64 & 128 & 256 \\
\hline $\begin{array}{l}\text { After adsorption } \\
\text { After heating } \\
\text { Cells chilled in eluate }\end{array}$ & $\begin{array}{l}+t+t \\
++ \\
+t+t\end{array}$ & $\begin{array}{c}++t+ \\
++ \\
++t\end{array}$ & $\begin{array}{c}+t+ \\
+ \\
++\end{array}$ & $\begin{array}{l}++ \\
0 \\
+\end{array}$ & $\begin{array}{l}+ \\
0 \\
+\end{array}$ & $\begin{array}{l}+ \\
0 \\
0\end{array}$ & $\begin{array}{l}0 \\
0 \\
0\end{array}$ \\
\hline
\end{tabular}

* Hemolysis in Donath-Landsteiner reaction

† Agglutination in indirect Coombs test (b)

$\ddagger$ Agglutination in indirect Coombs test (a)

and $2.5 \mathrm{ml}$. of a 1-2 dilution of guinea pig complement. After standing in the ice bath for 30 minutes, the mixture was centrifuged. Titration of the serum showed that all of the antibody had been adsorbed (Table II). The erythrocytes were then washed six times with cold saline, and were found to be agglutinable in antiglobulin serum (Table II). The sensitized cells were added to $1.5 \mathrm{ml}$. of saline and heated, with frequent shaking, at $56^{\circ} \mathrm{C}$ for eight minutes. The indirect Coombs test (a) indicated that antibody had been removed from the surface of the erythrocytes. The supernatant fluid obtained after centrifuging the heated cells was then used in place of $\mathrm{PCH}$ serum in the Donath-Landsteiner and indirect Coombs tests (Table II). This eluate contained approximately one-fourth the antibody found in the original serum. By using a serum with a high antibody titer, therefore, it was possible to adsorb repeatedly $\mathrm{PCH}$ antibody to erythrocytes and then demonstrate antibody in an eluate obtained by heating the erythrocytes at $56^{\circ} \mathrm{C}$. Such results were not obtained with normal serum examined in parallel with the $\mathrm{PCH}$ serum.

The effect of heat on both human and sheep erythrocytes was then studied. Human erythrocytes heated at $56^{\circ} \mathrm{C}$ for five to ten minutes were still capable of adsorbing antibody. When cells were held at this temperature for 15 minutes, many were destroyed, but the remaining cells adsorbed $\mathrm{PCH}$ antibody. Sheep cells so heated could still be sensitized by amboceptor. Sheep cells heated after sensitization were still hemolyzed when incubated with complement.

Comment: The demonstration that $\mathrm{PCH}$ antibody can be eluted from erythrocytes may aid in characterizing this antibody. Two facts made elution possible: 1 ) the failure of the antibody to act as a hemolysin in the absence of complement and 2) the stability of the antibody at $56^{\circ} \mathrm{C}$. Experiences with sera from the two patients indicate that the $\mathrm{PCH}$ serum must have a high antibody titer if antibody is to be detected in the erythrocyte eluate. The mechanism of the dissociation of the erythrocyte-antibody complex is not clear. The effect of heat was apparently not that of "receptor" destruction. The antibody must fix with complement, and it may be that heat releases the antibody by inactivating complement. Other antibodies, however, that do not require 
complement for fixation can also be eluted from erythrocytes by heating at $56^{\circ} \mathrm{C}(12-16)$.

Because antibody could not be demonstrated in eluates from cells sensitized in vivo or in vitro in the serum of case 2 , the elution technique did not help to clarify the nature of the "cell antibody" detected in the direct Coombs test.

Identification of $P C H$ serum factor reacting with antiglobulin serum as $P C H$ hemolysin

The use of antiglobulin serum to detect and measure $\mathrm{PCH}$ antibody indicated that agglutination in the indirect Coombs tests was dependent on the same serum factor that produced hemolysis in the Donath-Landsteiner reaction (4). The indications that this is true are summarized as follows :

1) Neither Coombs antibody nor hemolysin was adsorbed at $10-12^{\circ} \mathrm{C}$; both required $4^{\circ} \mathrm{C}$ for adsorption.

2) Coombs antibody and hemolysin were adsorbed simultaneously.

3) The titers of Coombs antibody and hemolysin were the same (4).

4) Both withstood heating at $62^{\circ} \mathrm{C}$ for 30 minutes.

5) There was a reciprocal relationship between the amount of complement present and both the amount of Coombs antibody fixed and the hemolysin titer (4).
6) Both, as will be indicated, are in the same serum fraction.

\section{The separation and characterization of the $P C H$ antibody}

Characterization of $\mathrm{PCH}$ antibody necessitated separation of the antibody from other serum components. The possibility existed that the patient's serum might contribute $C^{\prime} 1$ and $C^{\prime} 3$ activity or an abnormal component which would complete the hemolytic reaction in the presence of $\mathrm{C}^{\prime} 2$ and $C^{\prime} 4$. Fraction PI contained $C^{\prime} 1, C^{\prime} 3$, and $C^{\prime} 4$ but did not contain any $\mathrm{PCH}$ antibody (Table III). The precipitates formed when Fraction SI was dialyzed did not contain $\mathrm{PCH}$ antibody nor did they contain any of the components of complement. On the basis of these studies, which showed that the $\mathrm{PCH}$ antibody was not associated with $C^{\prime} 1, C^{\prime} 3$, and $C^{\prime} 4$, nor with the euglobulins which are insoluble between $\mathrm{pH} 5.0$ and 7.0, the possible association of $\mathrm{PCH}$ antibody with $\mathrm{C}^{\prime} 2$ or with the gamma globulins was next investigated.

The precipitates II + III, IV and V were examined for their $\mathrm{PCH}$ antibody content (Table III). II + III was the only fraction which contained PCH antibody. II + III prepared in the manner described above did not contain any of the known components of complement, and it was obvious that the $\mathrm{PCH}$ antibody was not associated with complement in human plasma.

TABLE III

Titration of PCH antibody in various fractions of serum

\begin{tabular}{|c|c|c|c|c|c|c|c|c|c|c|c|}
\hline \multirow{3}{*}{$\underset{\text { fraction }}{\text { Serum }}$} & \multicolumn{11}{|c|}{ Antibody titration } \\
\hline & \multicolumn{5}{|c|}{ Hemolysin } & \multicolumn{6}{|c|}{ Indirect Coombs (b) } \\
\hline & Undiluted & 2 & 4 & 8 & 16 & Undiluted & 2 & 4 & 8 & 16 & 32 \\
\hline $\begin{array}{l}\text { Original } \\
\text { plasma } \\
\text { PI* } \\
\text { II + III*† } \\
\text { IV* }^{*} \\
\text { V* }^{*} \\
\text { II } \ddagger \\
\text { III-1 } \\
\text { II E\$ } \\
\text { II S\$ }\end{array}$ & $\begin{array}{c}+++ \\
0 \\
0 \\
0 \\
0 \\
+++ \\
++ \\
0 \\
++\end{array}$ & $\begin{array}{c}++ \\
0 \\
+ \\
0 \\
0 \\
++ \\
+ \\
0 \\
+\end{array}$ & $\begin{array}{c}+ \\
0 \\
++ \\
0 \\
0 \\
++ \\
0 \\
0 \\
0\end{array}$ & $\begin{array}{l}0 \\
0 \\
+ \\
0 \\
0 \\
+ \\
0 \\
0 \\
0\end{array}$ & $\begin{array}{l}0 \\
0 \\
0 \\
0 \\
0 \\
0 \\
0 \\
0 \\
0\end{array}$ & $\begin{array}{c}+++ \\
0 \\
+++ \\
0 \\
0 \\
++++ \\
++++ \\
0 \\
++++\end{array}$ & $\begin{array}{c}++ \\
0 \\
+++ \\
0 \\
0 \\
++++ \\
+++ \\
0 \\
+++\end{array}$ & $\begin{array}{c}++ \\
0 \\
+++ \\
0 \\
0 \\
+++ \\
0 \\
0 \\
++\end{array}$ & $\begin{array}{c}0 \\
0 \\
++ \\
0 \\
0 \\
+++ \\
0 \\
0 \\
0\end{array}$ & $\begin{array}{l}0 \\
0 \\
++ \\
0 \\
0 \\
+ \\
0 \\
0 \\
0\end{array}$ & $\begin{array}{l}\mathbf{0} \\
\mathbf{0} \\
\mathbf{0} \\
\mathbf{0} \\
0 \\
\mathbf{0} \\
\mathbf{0} \\
\mathbf{0} \\
\mathbf{0}\end{array}$ \\
\hline
\end{tabular}

* Fraction concentrated five times with respect to original plasma.

+ II + III anticomplementary in dilutions through $1-4$.

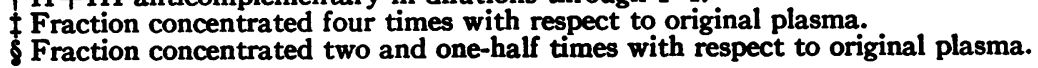


When II + III was separated into water soluble (II + IIIS) and water insoluble (II-+ IIIE) fractions, $\mathrm{PCH}$ antibody was found in both of these fractions. II + IIIS and II + IIIE were therefore combined (II + III) and fractionated into II and III -1 . Practically all of the $\mathrm{PCH}$ activity was found in Fraction II. Small amounts were found in III -1 . Electrophoretic analysis of Fraction II revealed that it was entirely homogeneous with a mobility identical to that of the gamma globulins.

When Fraction II was separated into water soluble (IIS) and water insoluble (IIE) fractions, all of the $\mathrm{PCH}$ antibody was found in IIS indicating that this antibody is associated with water soluble gamma globulins and resembles most other human antibodies in this respect (9).

Comment: It is apparent that none of the known components of complement are associated with $\mathrm{PCH}$ antibody. In fact, the antibody is a gamma globulin.

$\mathrm{PCH}$ antibody in Fraction II + III behaved as though it was a euglobulin but actually showed its true pseudoglobulin character in Fraction II. This discrepancy may be due to interactions occurring between $\mathrm{PCH}$ antibody and other globulins in II + III. The removal of alpha and beta globulins allowed the antibody to exhibit its solubility in water.

While most of the $\mathrm{PCH}$ antibody was present in II, small amounts were found in III -1 . The gamma globulin originally present in II + III was distributed in the proportion of 80 per cent in II and 20 per cent in III -1 . Thus, the activity found in III - 1 may be accounted for by the presence of small amounts of gamma globulin in this fraction. When Fraction II was separated into euglobulins and pseudoglobulins, all of the antibody activity was associated with the water soluble gamma globulins (IIS). Fraction IIS contains other antibodies as well as the $\mathrm{PCH}$ antibody (9), and it is hoped that PCH antibody can be separated from IIS by adsorption and elution. The possibility still exists that a serum factor independent of complement and antibody is concerned in the hemolysis of paroxysmal cold hemoglobinuria. Complete elucidation of this problem must await studies with pure components of complement and pure $\mathrm{PCH}$ antibody.
SUM M ARY

Erythrocytes from a patient with paroxysmal cold hemoglobinuria $(\mathrm{PCH})$ were found to be agglutinable in antiglobulin serum (direct Coombs test). Although these erythrocytes had been "sensitized" in vivo, they were not hemolyzed when warmed with complement. The cells, however, were hemolyzed, both in vivo when the patient was chilled, and in vitro when they were chilled and warmed in $\mathrm{PCH}$ serum.

The patient's cells were no longer agglutinable in antiglobulin serum six hours after in vivo hemolysis. No concomitant change in either serum antibody or complement level was detected. Further characterization of the "cell antibody" responsible for agglutination in the direct Coombs test was not possible since the factor could not be demonstrated in eluates from the patient's erythrocytes.

The behavior of the abnormal antibody present in the sera of two patients with $\mathrm{PCH}$ was studied by using antiglobulin serum (indirect Coombs test) as well as the Donath-Landsteiner reaction. Antibody adsorbed in vitro from serum with a high antibody titer could be eluted from erythrocytes by heating the cells at $56^{\circ} \mathrm{C}$.

The PCH serum factor which reacts with antiglobulin serum was identified as the $\mathrm{PCH}$ hemolysin.

Fractionation of $\mathrm{PCH}$ serum in alcohol-water systems revealed that the $\mathrm{PCH}$ antibody is a water soluble (pseudoglobulin) gamma globulin and resembles most other human antibodies in this respect.

\section{ACKNOWLEDGMENT}

The technical assistance of Miss Marjorie Newton and Miss Sylvia Rowihab is gratefully acknowledged.

\section{REFERENCES}

1. Donath, J., and Landsteiner, K., Ueber paroxysmale Hämoglobinurie. München med. Wchnschr., 1904, 51, 1590.

2. Mackenzie, G. M., Observations on paroxysmal hemoglobinuria. J. Clin. Invest., 1929, 7, 27.

3. Mackenzie, G. M., Paroxysmal hemoglobinuria, a review. Medicine, 1929, 8, 159.

4. Jordan, W. S., Jr., Pillemer, L., and Dingle, J. H., The mechanism of hemolysis in paroxysmal cold hemoglobinuria. I. The role of complement and 
its components in the Donath-Landsteiner reaction. J. Clin. Invest., 1951, 30, 11.

5. Coombs, R. R. A., Mourant, A. E., and Race, R. R., Detection of weak and incomplete $\mathrm{Rh}$ agglutinins : A new test. Lancet, 1945, 2, 15.

6. Siebens, A. A., Zinkham, W. H., and Wagley, P. F., Observations on the mechanism of hemolysis in paroxysmal (cold) hemoglobinuria. Blood, 1948, 3, 1367.

7. Cohn, E. J., Properties and functions of plasma proteins, with consideration of methods for their separation and purification. Chem. Rev., 1941, 28, 395.

8. Cohn, E. J., Strong, L. E., Hughes, W. L., Jr., Mulford, D. J., Ashworth, J. N., Melin, M., and Taylor, H. L., Preparation and properties of serum and plasma proteins. IV. A system for the separation into fractions of the protein and lipoprotein components of biological tissues and fluids. J. Am. Chem. Soc., 1946, 68, 459.

9. Edsall, J. T., The plasma proteins and their fractionation, in Advances in Protein Chemistry, New York, Academic Press, Inc., 1947, Vol. 3, p. 383.

10. Deutsch, H. F., Gosting, L. J., Alberty, R. A., and Williams, J. W., Biophysical studies of blood plasma proteins. III. Recovery of $\gamma$-globulin from human blood protein mixtures. J. Biol. Chem., 1946, 164, 109.

11. Jordan, W. S. Jr., Prouty, R. L., Heinle, R. W., and Dingle, J. H., The mechanism of hemolysis in paroxysmal cold hemoglobinuria. III. Erythrophagocytosis and leukopenia. In preparation.

12. Evans, R. S., and Duane, R. T., Acquired hemolytic anemia. I. The relation of erythrocyte antibody production to activity of the disease. II. The significance of thrombocytopenia and leukopenia. Blood, 1949, 4, 1196.

13. Landsteiner, K., and Miller, C. P., Jr., Serological studies on the blood of primates. II. The blood groups in anthropoid apes. J. Exper. Med., 1925, $42,853$.

14. Hill, J. M., and Haberman, S., Demonstration of Rh antibodies in the new-born and further evidence of the pathogenesis of erythroblastosis. I. Lab. \& Clin. Med., 1946, 31, 1053.

15. Evans, R. S., Duane, R. T., and Behrendt, F., Demonstration of antibodies in acquired hemolytic anemia with anti-human globulin rabbit serum. Proc. Soc. Exper. Biol. \& Med., 1947, 64, 372.

16. Sturgeon, P., A new antibody in serum of patients with acquired hemolytic anemia. Science, 1947, 106, 293. 